\title{
TTR
}

Traduction, terminologie, rédaction

\section{Michael Cronin. Translation and Identity. Oxford/New York, Routledge, 2006, 166 p.}

\section{Gillian Lane-Mercier}

Volume 21, numéro 1, 1er semestre 2008

La formation en traduction : pédagogie, docimologie et technologie I

Translator Training: Pedagogy, Evaluation, and Technologies I

URI : https://id.erudit.org/iderudit/029692ar

DOI : https://doi.org/10.7202/029692ar

Aller au sommaire du numéro

\section{Éditeur(s)}

Association canadienne de traductologie

\section{ISSN}

0835-8443 (imprimé)

1708-2188 (numérique)

Découvrir la revue

\section{Citer ce compte rendu}

Lane-Mercier, G. (2008). Compte rendu de [Michael Cronin. Translation and Identity. Oxford/New York, Routledge, 2006, 166 p.] TTR, 21(1), 241-247.

https://doi.org/10.7202/029692ar

Tous droits réservés (C) TTR: traduction, terminologie, rédaction — Les auteurs, 2009
Ce document est protégé par la loi sur le droit d'auteur. L’utilisation des services d'Érudit (y compris la reproduction) est assujettie à sa politique d'utilisation que vous pouvez consulter en ligne.

https://apropos.erudit.org/fr/usagers/politique-dutilisation/ 


\section{COMPTES RENDUS}

\section{Michael Cronin. Translation and Identity. Oxford/New York, Routledge, 2006, 166 p.}

Building on facets of his previous work, Translation and Identity by Michael Cronin offers a brilliant rethinking of the conceptual basis for translation theory and practice in an attempt to account for the latter's role in the era of globalization. As Cronin convincingly demonstrates, neither the reassuring binaries of modernity nor the well-worn paradigms of translation studies enable us to comprehend the linguistic and cultural complexities of the contemporary moment, the questions of identity they raise and the central place they must assign to translation. Rather, a whole new set of concepts and distinctions is needed to identify just what is at stake for the study and practice of translation in a post-nationalist world where traditional political, social, ethnic, cultural and literary boundaries no longer hold against the borderless flux of migratory forces, information technology, cross-cultural communication and neo-liberal economies.

Translation and Identity thus proposes, on one level, a rich, eclectic palette of interlocking notions drawn from a number of disciplines which allows Cronin to illustrate at once the omnipresence and the inevitability of translational practices in today's global society, together with the historical backdrop against which these practices can be understood. On another level, these notions are consistently grounded in well documented references to the often painful experiences of everyday existence where local cultures must be defended or surrendered, wars continue to be fought, immigrants face the difficult choice of assimilation or exclusion, translators/interpreters fear at times for their lives and millions live in translation. By constantly weaving between the theoretical and the experiential, the past and the present, the local and the global, the oral and the written, as well as between a large array of disciplines and source materials, Cronin's demonstration not only avoids the binaries and paradigms it denounces, it could also be seen as embodying the very contributions he believes translation can and should make to the contemporary debates around identity: innovativeness, connectivity and reciprocity. 
In chapter 1 , Cronin poses a number of key distinctions that quickly lead him to offer a multifaceted definition of the central concept in which his subsequent analyses of contemporary translation theory and practice are grounded: micro-cosmopolitanism. On the one hand, micro-cosmopolitism is symptomatic of the emergence of a new cosmopolitanism that, while it contains many of the ideals implicit in more traditional conceptions, such as the "ideal of humanity as a collection of free and equal beings, possessing the same basic rights and to whom notions of hospitality, openness to others and freedom of movement are primordial" (8), nonetheless eschews the "perverse effects" these conceptions often produce. On the other hand, micro-cosmopolitanism provides a conceptual framework for better articulating and understanding the relationship between the local and the global, the particular and the universal, the self and the other at the core of contemporary thinking on translation. Indeed, the most powerful defining feature of microcosmopolitanism is its ability to at once reconnect the opposing poles that binary systems are so anxious to uphold, undermine the hierarchies that enable them to do so, and reverse dominant ideological and theoretical trends by arguing that "the same degree of diversity is to be found at the level of entities judged to be small or insignificant as at the level of large entities." (15)

In other words, a micro-cosmopolitan approach is one that operates from below rather than from above by situating cultural and linguistic foreignness, difference and exchange (read: translation) within the local, henceforth perceived in all its dynamic complexity, as well as its potential for interconnectedness and solidarity on both the local (inward) and global (outward) dimensions. It is an approach that simultaneously avoids reductive nationalisms, disincarnated, condescending macrocosmopolitanisms and neo-imperialistic transnationalisms in an attempt to "define specificity through and not against multiplicity" (18), thereby offering a much needed alternative to (neo)liberal notions of multiculturalism and cultural pluralism. Synonymous with recently defined concepts such as global hybrids, mutable mobiles, quantum duality and bottom-up localization, micro-cosmopolitanism is based on non-essentialist, porous, interdependent conceptions of origin, belonging and 
being that, according to Cronin, best describe what is at stake for contemporary translators. In this sense, translation is akin to what Gerard Delanty has described as the cosmopolitan moment which "occurs when context-bound cultures encounter each other and undergo transformation as a result" (cited p. 23), thereby consecrating the "wave-like" connection between the national (micro) and the transnational (macro). As a mobilizing, transformative, cosmopolitan practice, translation articulates the fundamental characteristics of a micro-cosmopolitan vision of cultural experience and inward/outward interconnectedness, which in turn is a consequence, at least partially, of what could be considered one of the most important transcultural, transnational and translational phenomena of the late $20^{\text {th }}$ Century: migration.

Chapter 2 focuses more specifically on how, in our contemporary societies, micro-cosmopolitanism can result from immigration, on the one hand, and, on the other, how the latter is responsible for the growing centrality of translation and the emergence of new identitarian paradigms. By doing so, it seeks to explore "the issues that must be addressed if translation studies is to make an effective contribution to debates on a topic which is (...) often deeply and dangerously divisive" (46). After briefly commenting on the various ways culture may be defined, as well as the extent to which each definition entails different ways of conceptualizing/responding to difference in a globalized context where migration plays an increasingly key role, Cronin positions himself clearly with respect to the debate: "at the level both of self and culture, open-ended interdependency is a more credible candidate than essentialist autonomy for thinking about forms of living in interconnectedness" (50). He then goes on to identify two translational strategies immigrants may adopt with respect to their new linguistic and cultural situation: either they opt for translational assimilation, "where they seek to translate themselves into the dominant language of the community," or they opt for translational accommodation, "where translation is used as a means of maintaining their languages of origin" (52).

While neither option is without its problems, they both adhere to the logic of micro-cosmopolitanism. Translational assimilation, which relies heavily on the presence of institutional 
structures (language classes, etc.) to provide appropriate access to the host language, tends to facilitate social and economic integration, although this is often more the case for men than for women. Moreover, immigrants already in possession of a form of "global English," for example, may encounter difficulties when faced with a local variety (such as Irish English) and find themselves obliged to resort to a dual translation process (mother tongue $\rightarrow$ global language $\rightarrow$ local language) according to which "difference engenders more difference" (p. 55). In turn, this process creates new forms of interconnectedness and mobility as immigrant speakers impact on the host language by leaving traces of the translation process that, over time, lead to its transformation.

Conversely, translational accommodation is anchored in a fear of total assimilation, a desire to resist being translated into the target language and to assert equal language rights. This necessitates the presence of quite different institutional structures within the host community, including interpreting services and a variety of source language programs. More specifically, it points to the manner in which global migratory flows have opened up the local from within to new complexities that foster transnational connections by way of a visible, permanent and intrinsic translation activity designed to consolidate multilingualism through integration rather than to eradicate it through assimilation. "Difference from this perspective, then, is something which binds rather than divides" (63) - a stance that is in obvious opposition to multicultural discourses based on "noninteractive indifference" (68) and whose existence is a direct result of the demands put on translation by migration in the public and private spheres alike. Translation is vital for migrant societies in general and for the construction of a dialogical, transnational migrant identity in particular. Hence the urgency of taking stock not of the visibility of the translator/the immigrant-as-translator, but of his/her audibility.

This is precisely what Cronin does in chapter 3, which is devoted to the history of interpreting defined as an oral activity distinct from translation, construed as a textual practice. Central to his demonstration is the idea of embodied agency: the interpreter 
is a culturally and ideologically determined "speaking body" who is acutely conscious of the possible outcome(s) of interpreting, which include prestige, power, betrayal, torture and death. Here the notion of divided loyalties takes on its full meaning, for not only is the interpreter bound as much by content as by context, but the latter can, especially in situations of conflict, bring with it fatal consequences for the interpreter him/herself. Taking Ireland as an example, Cronin turns to literary texts, songs and folklore, as well as to chronicles, legal texts and rhetorical treatises in which interpreters are characters or interpreting is thematized to illustrate his point: interpreting-or the absence thereofis a powerful political tool that, alternatively, can facilitate interaction between equals, support linguistic hegemonies through intimidation or manipulation and symbolize resistance. In this sense, embodiment assumes an added meaning insofar as, historically, interpreters "occupy a metonymical relationship to the cause they serve and come to embody;" as such, they "represent the very real human dilemmas of a population who find themselves caught up in violent conflict or war" (88-89).

Perhaps the most fascinating sections of this chapter are the ones in which Cronin uses Shakespearean drama to examine the link between translation, English imperialism and identity in early $17^{\text {th }}$ century England and Ireland in order to remind us that identity issues are not the preserve of the late $20^{\text {th }}$ century. He begins by recalling that empirical expansion and linguistic expansion, on the one hand, and eloquence and translation, on the other hand, are inseparable, for they all imply power relations based on exploitation, expropriation and reappropriation. Thus, by expanding the resources of the English language, Shakespeare rendered it better apt to be the language of empire, in which translators wielded, per force, significant amounts of authority and power. Cronin goes on to hypothesize that "what we find in his work is a recognition that the construction of the nation and by extension the beginning of empire constitute among other things an exercise in translation" (97) and that, for Shakespeare, "the figure of translation is a way of exploring the metamorphic journey of the Tudors on their way to elaborating new conceptions of identity" (106). He then proceeds to analyze the portrayal of translation in Shakespeare's plays as a transformative practice 
that is systematically viewed with suspicion, even fear, due to the interpreter's ability to deceive by shifting his loyalties and/or to the way translation can brutally alter one's condition. This allows him to establish a parallel between translation as forging the (vernacular) language, translation as forging the nation and a new national identity, and translation as forgery, that is, the reading of translated Irish subjects as if they were "British originals"-a posture that will be denounced by Irish cultural nationalism at the end of the $19^{\text {th }}$ century.

The concluding sections of chapter 3 introduce the book's last chapter. Returning to the present, Cronin underscores the ongoing dangers translators and interpreters face in the context of contemporary informational warfare, notably in Iraq where they "are being targeted with particular ferocity" (113), a situation he believes will only intensify in the course of the $21^{\text {st }}$ century. Hence the relevancy of the historical overview just provided, in which the "monstrous doubleness" (114) of interpreters, their potential to deceive and defect, has consistently reinforced their status as embodied agents who assume very real risks. As Cronin points out, perhaps one of the most difficult problems interpreters have always faced is whether they can ever return "as natives" to their language/culture of origin. Dangerous as it may be, the interpreter's return home can, however, have the more positive effect of injecting the global into the local, thereby transforming the local into a site of micro-cosmopolitanism and the interpreter, by virtue of his/her very duplicity, into a quintessentially microcosmopolitan subject whose "polyidentity" (117) is grounded in multiple forms of cultural interconnectedness and allegiances that prevent "the violent and dogmatic synthesis of binary opposites" (118).

Cronin develops this positive vision in his shorter final chapter, in which he denounces the "regressive threat" of monoculturalism and monolingualism inherent to nationalist ideologies as well as to neo-imperialistic globalizing forces. The practice of translation, with its power to connect that which is initially separate, should be well-equipped to counter such a threat as long as one keeps in mind that "translation has as much a vested interest in distinctness as in connectedness" (121), although to do 
so is not easy given wide-spread perceptions of globalization as homogenization, standardization and translational assimilation, and of translation as imitation, misrepresentation and loss. Prevalent in critical discourses throughout the $20^{\text {th }}$ century, such perceptions reveal a generalized belief in the entropic decline in (translation's ability to maintain) cultural diversity which recent globalizing tendencies have consistently exacerbated. Refusing to give currency to this belief, Cronin redefines translation from a micro-cosmopolitan perspective as a negentropic cultural activity concerned with "the way in which translation contributes to and fosters the persistence and development of diversity" (129)—or, as he calls it, diversality, as opposed to universality. Rather than equating linguistic complexity with the failure of translation, he states that "it is because so much cannot be translated that much more remains to be translated" (130). Translation needs the fractal complexity of the local to exit, the understanding that the particular contains an image of the whole; it needs to show that "diversity persists in the elaborateness of the particular" (133) and that there is still something to express. Micro-cosmopolitanism thus implies an ethics of translation "which is predicated on complexity, distance and desire" (135), that is, on a connectedness that links the local to the global. As such, it "has much to tell us about how humans (...) live in a world where to know who you are means first and foremost knowing who others are" (143).

Gillian Lane-Mercier McGill University

\section{Barbara Folkart. Second Finding: A Poetics of Translation. Ottawa, University of Ottawa Press, 2007, 562 p.}

The title of Barbara Folkart's second academic monograph, Second Finding: A Poetics of Translation, is taken from Richard Wilbur's poem The Beautiful Changes (1988) $)^{1}$ and displayed on the book's cover in three experimental re-inscriptions, all set against a

1 Wilbur, Richard (c. 1988). New and Collected Poems. San Diego, New York, London, Harcourt Brace Jovanovich. 